\title{
EASTERN YELLOW-BELLIED RACER POPULATIONS ON THE CANADIAN PRAIRIES
}

Laura E. Gardiner ${ }^{1,2}$, Jessica A. Martino ${ }^{1}$, Ray G. Poulin ${ }^{2},{ }^{*}$, Christopher M. Somers $1,{ }^{*}$

${ }^{1}$ Department of Biology, University of Regina, Regina, SK, S4S 0A2; 'E-mail: <chris. somers@uregina.ca>

${ }^{2}$ Royal Saskatchewan Museum, Regina, SK, Canada, S4P 2V7; *E-mail: <ray.poulin@ gov.sk.ca>

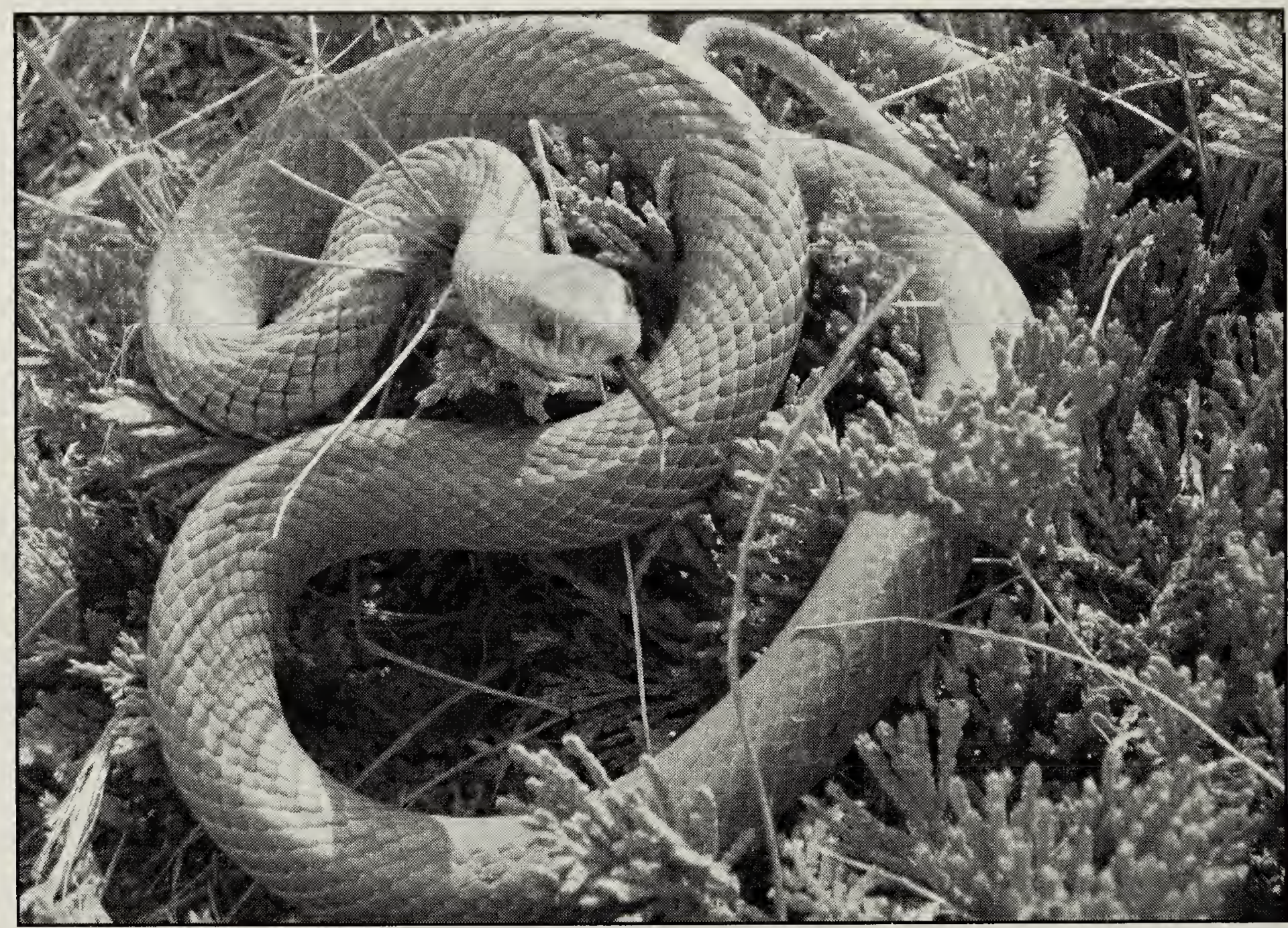

Figure 1. Threatened eastern yellow-bellied racer in a creeping juniper patch at the Snake Pit hibernaculum, the largest known snake hibernaculum in Grasslands National Park, SK.

Laura Gardiner

The eastern yellow-bellied racer (Coluber constrictor flaviventris; Fig. 1) has been identified as a Species at Risk in Canada, with previously published observations suggesting that its range was confined to small areas in southern
Saskatchewan in the Big Muddy and Frenchman River Valleys. ${ }^{1}$ In particular, Grasslands National Park has been the only confirmed location for a population of this snake for some time. The eastern yellow-bellied racer has been assessed 


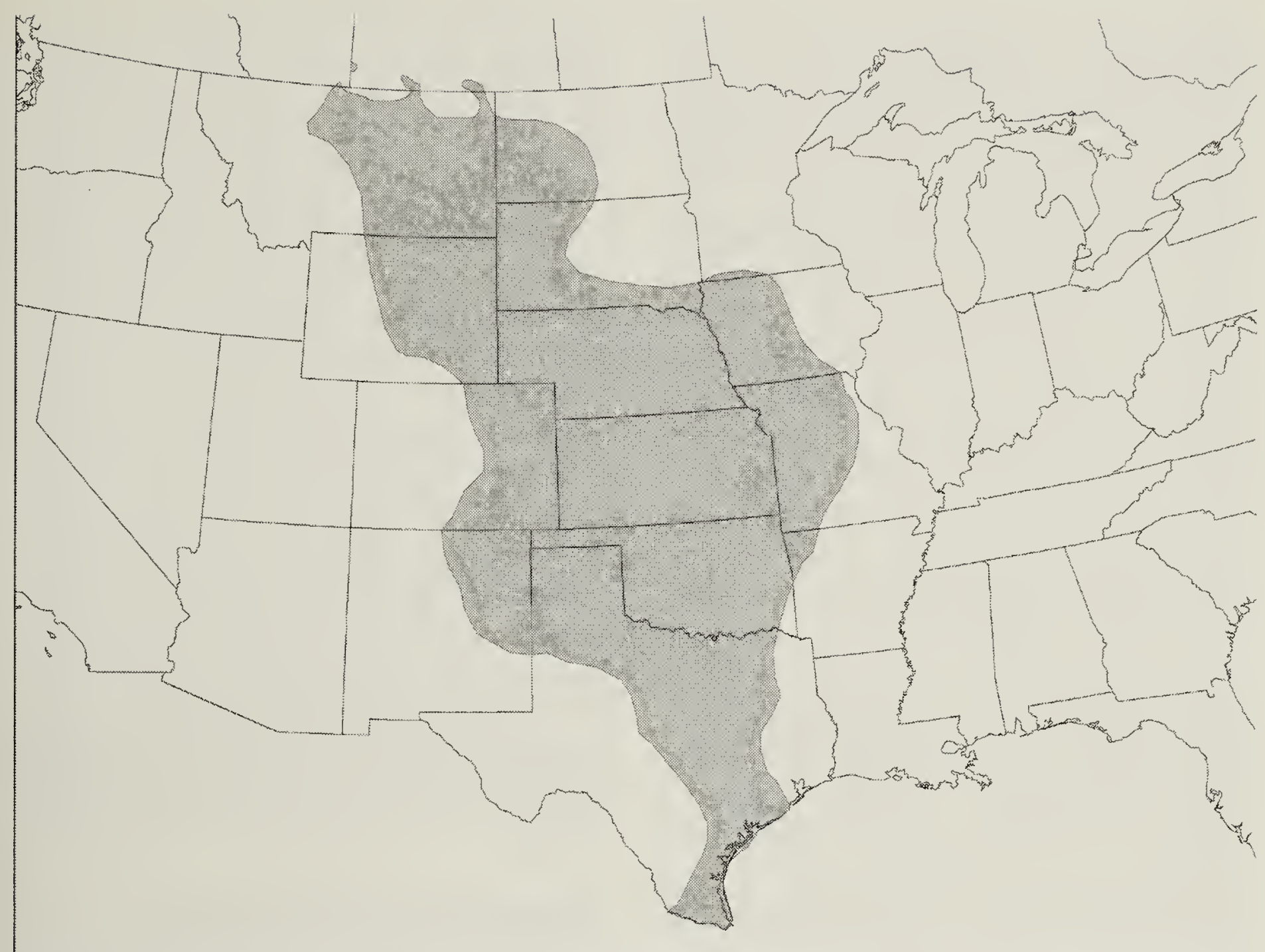

Figure 2. Geographic range of the eastern yellow-bellied racer in North America. Canadian populations are at the northern extreme of the range for this snake species.

as Threatened with extinction by the Committee on the Status of Endangered Wildlife in Canada (COSEWIC) because of its small geographic range and specific requirements for suitable overwintering sites (hibernacula). ${ }^{1,2}$ Little information is currently available on the basic ecology of the eastern yellow-bellied racer in Canada, and its distribution and abundance are poorly documented.

Canadian populations of the eastern yellow-bellied racer in Saskatchewan are at the northern extent of a broad geographic range that is largely in the United States (Fig. 2). ${ }^{1}$ Populations of this racer in Canada likely originated from, and may still be connected to, southern populations closer to the core of their range. Previously, the reported range for eastern yellow-bellied racers in Canada only included the Frenchman
River Valley and Big Muddy Valley, as these snakes had not been found outside these major river valley systems. However, recent evidence suggests that the eastern yellow-bellied racer may be, or is becoming, more widespread on the Canadian Prairies than was previously thought.

\section{Frenchman River Valley, Saskatchewan}

The eastern yellow-bellied racer has long been known to inhabit the Frenchman River Valley in the area within Grasslands National Park; however, formal study of this species in the area only began recently. ${ }^{3-6}$ In 2006, the Val Marie Prairie Farm Rehabilitation Administration (PFRA) pasture manager found a road-killed eastern yellow-bellied racer on PFRA land about $12 \mathrm{~km} \mathrm{NW}$ of the town of Val Marie (T. Platt, PFRA 
pers. comm.). This was the first record of an eastern yellow-bellied racer north of the boundaries of Grasslands National Park. In 2007, researchers and Parks Canada staff began searching for dens and studying the eastern yellow-bellied racer in response to the species being listed as Threatened by COSEWIC in 2004. Research in 2007 on Val Marie PFRA land led to the discovery of the first known hibernaculum to contain the eastern yellow-bellied racer outside of Grasslands National Park. This den was also inhabited by plains garter snakes (Thamnophis radix), prairie rattlesnakes (Crotalus viridis), and bullsnakes (Pituophis catenifer sayi). In 2009, a second hibernaculum housing the eastern yellow-bellied racer was discovered in the same PFRA pasture; this den was also inhabited by plains garter snakes and bullsnakes. For both new dens, it was the radio-tracking of bullsnakes that led to their discovery. As of 2011, there were seven known eastern yellow-bellied racer den sites in the Frenchman River Valley, mainly inside of Grasslands National Park. ${ }^{7}$ Recent mark-recapture population size estimates using the Lincoln-Petersen formula (three recaptures of 24 previously marked snakes in a sample of 43 snakes in 2010), suggest that over 300 eastern yellow-bellied racers inhabit the Snake Pit hibernaculum, the largest known den site in Grasslands National Park.

\section{Big Muddy Valley, Saskatchewan}

The first eastern yellow-bellied racer found in the Big Muddy Valley in southcentral Saskatchewan was caught on a private ranch in $1968 .{ }^{8}$ In 1976, a second specimen was found in the same area. ${ }^{9}$ These two individual events suggest that eastern yellow-bellied racers occupy the Big Muddy Valley, but they have not been studied in that area, and the extent and size of the local population are completely unknown. ${ }^{5,6}$ In May 2010, a road-killed eastern yellow-bellied racer was found
(D. Hjertaas, Saskatchewan Watershed Authority, pers. comm.) $36 \mathrm{~km} \mathrm{NW}$ of the 1968 and 1976 capture sites. This discovery prompted further investigation for potential den sites in the area. A live bullsnake and an eastern yellow-bellied racer were captured in the area later in May of 2010. The bullsnake was implanted with a transmitter and radio-tracked to its hibernaculum in the fall of 2010 , resulting in the discovery of the first known den site to contain the eastern yellow-bellied racer outside of the Frenchman River Valley. The new hibernaculum site extended the confirmed distribution of eastern yellowbellied racers towards the north-western portion of the Big Muddy Valley. In total, three adult eastern yellow-bellied racers and eight adult bullsnakes were found in the area in 2010 (Fig. 3, see outside back cover).

\section{Cypress Hills, Saskatchewan}

In 1998, an eastern yellow-bellied racer was observed within $0.5 \mathrm{~km}$ of Fort Walsh in the Cypress Hills. ${ }^{10}$ To our knowledge, this was the first recorded observation of the species in the area. In 2009, a second observation of a snake that matched the description of an eastern yellow-bellied racer was made $1 \mathrm{~km}$ west of Fort Walsh (J. Poissant, University of Regina, pers. comm.), very near the previous sighting from 11 years prior. Combined, these two observations suggest that a previously undocumented eastern yellow-bellied racer population may inhabit the Cypress Hills area. This is significant because it not only suggests a separate, isolated population, but it would also be the only known population to exist outside of a major river valley system in Canada (i.e. Milk, Frenchman, or Big Muddy).

\section{Onefour, Alberta}

Since 2001 , one probable and four confirmed sightings of eastern yellowbellied racers have occurred in extreme south-eastern Alberta, near Onefour and 


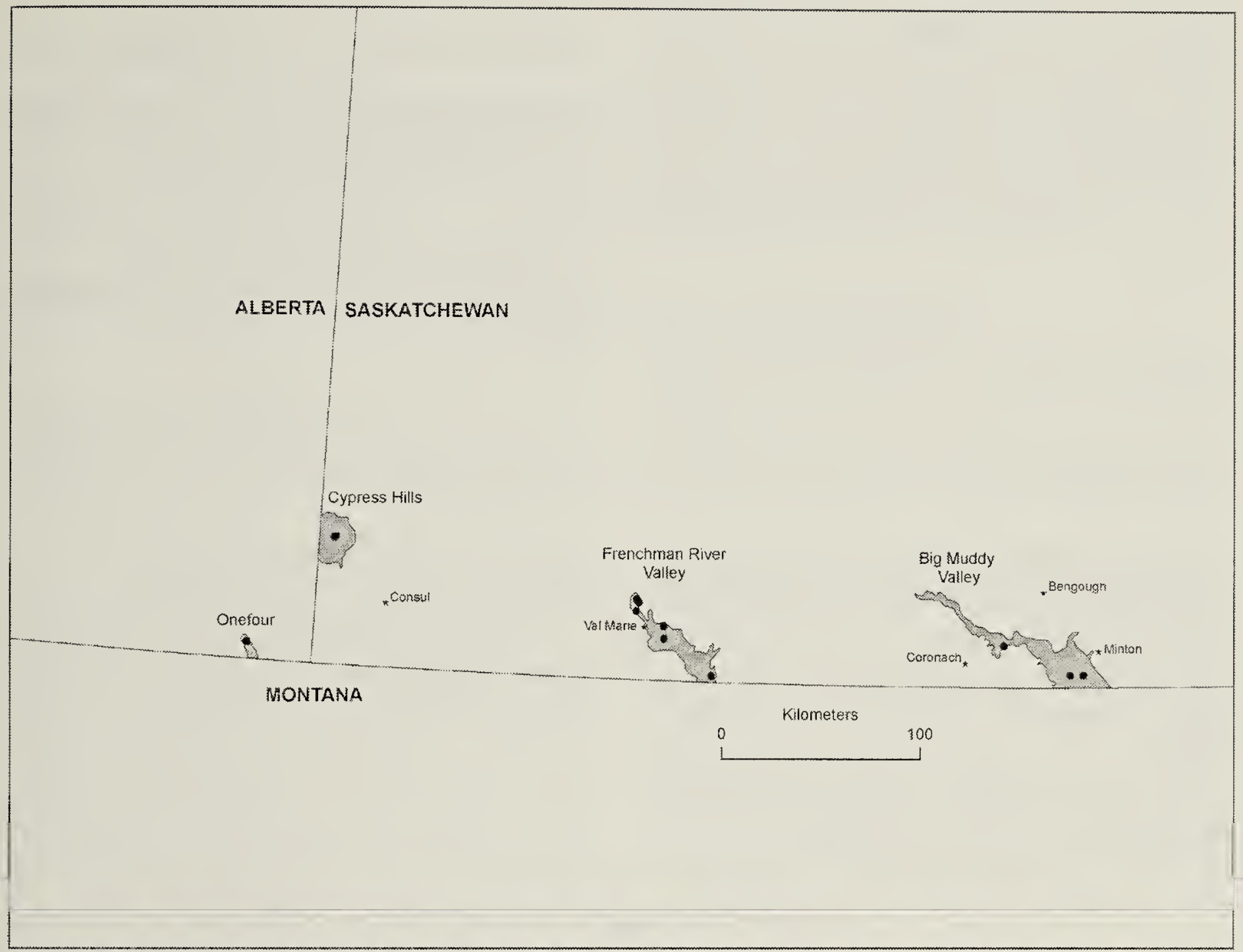

Figure 4. Updated geographic range of the eastern yellow-bellied racer in Canada. Black dots represent confirmed eastern yellow-bellied racer locations; gray shading is the possible area occupied by the eastern yellow-bellied racer based on potentially suitable habitat.

Lost River. ${ }^{1,7}$ These are the first known records of eastern yellow-bellied racers in Alberta. These sightings suggest another, potentially separate population in the Canadian Prairies. The first record from Onefour was an observation of a burrowing owl (Athene cunicularia) bringing a dead eastern yellow-bellied racer to its burrow. ${ }^{1}$ What was left of the specimen was later collected from just outside the burrow entrance on 29 May 2001, and is currently part of the collections at the Royal Alberta Museum (I. Kriston, Royal Alberta Museum, pers. comm.).

Interestingly, there could be four unconnected populations of the eastern yellow-bellied racer in the Canadian Prairies (Fig. 4). Population genetics studies are currently underway to evaluate how the various groups of eastern yellowbellied racers may be interconnected (C. Somers, unpublished data). Seven known den sites have been identified as critical habitat for eastern yellow-bellied racers within the Frenchman River Valley; however, the observations from Cypress Hills and Onefour, in addition to the den located in Big Muddy Valley, warrant further investigation for den sites in these areas. Recent eastern yellowbellied racer sightings outside of the Val Marie/Grasslands National Park area may be due to several factors: (a) it is possible that eastern yellow-bellied racers are more widespread and abundant in Canada than previously thought; (b) more search effort may be resulting in the 'discovery' of populations that were 
simply unnoticed before; or (c) eastern yellow-bellied racers may be extending their range northward. It is currently impossible to distinguish among these possibilities; there is clearly a need for additional research on this species in Canada.

1. COSEWIC (2004) COSEWIC assessment and update status report on the Eastern and Western Yellow-bellied Racers, Coluber constrictor flaviventris and Coluber constrictor mormon in Canada. Committee on the Status of Endangered Wildlife in Canada, Ottawa, ON.

2. Brown WS, Parker WS (1976) Movement ecology of Coluber constrictor near communal hibernacula. Copeia 1976:225-242.

3. Maher WJ, Beck WH (1964) Two records of the yellow-bellied racer in Saskatchewan. Blue Jay 22:174.

4. Lynch W (1978) Death-feigning in the eastern yellow-bellied racer. Blue Jay 36:92-93
5. Finley KJ, Jasieniuk MA (1978) The eastern yellowbellied racer in Canada. Blue Jay 36:88-91.

6. Cook FR, van Zyll de Jong CG (1975) Eastern yellow-bellied racer in central southern Saskatchewan. The Canadian Field-Naturalist 89:174-175.

7. Parks Canada Agency (2010) Recovery Strategy for Eastern Yellow-bellied Racer (Coluber constrictor flaviventris) in Canada. Species at Risk Act Recovery Strategy Series. Parks Canada Agency, Ottawa, ON.

8. Morrison $\mathrm{H}$ (1969) A preliminary botanical survey of the Big Muddy Valley in southern Saskatchewan. Blue Jay 27:42-53

9. Kreba R (1978) Observations of an eastern yellowbellied racer in captivity. Blue Jay 36:94-98.

10. Schmutz JK, Picotte J (1998) Observations of reptiles and amphibians, and thoughts on conservation in prairie Canada. Blue Jay 56:169-182.

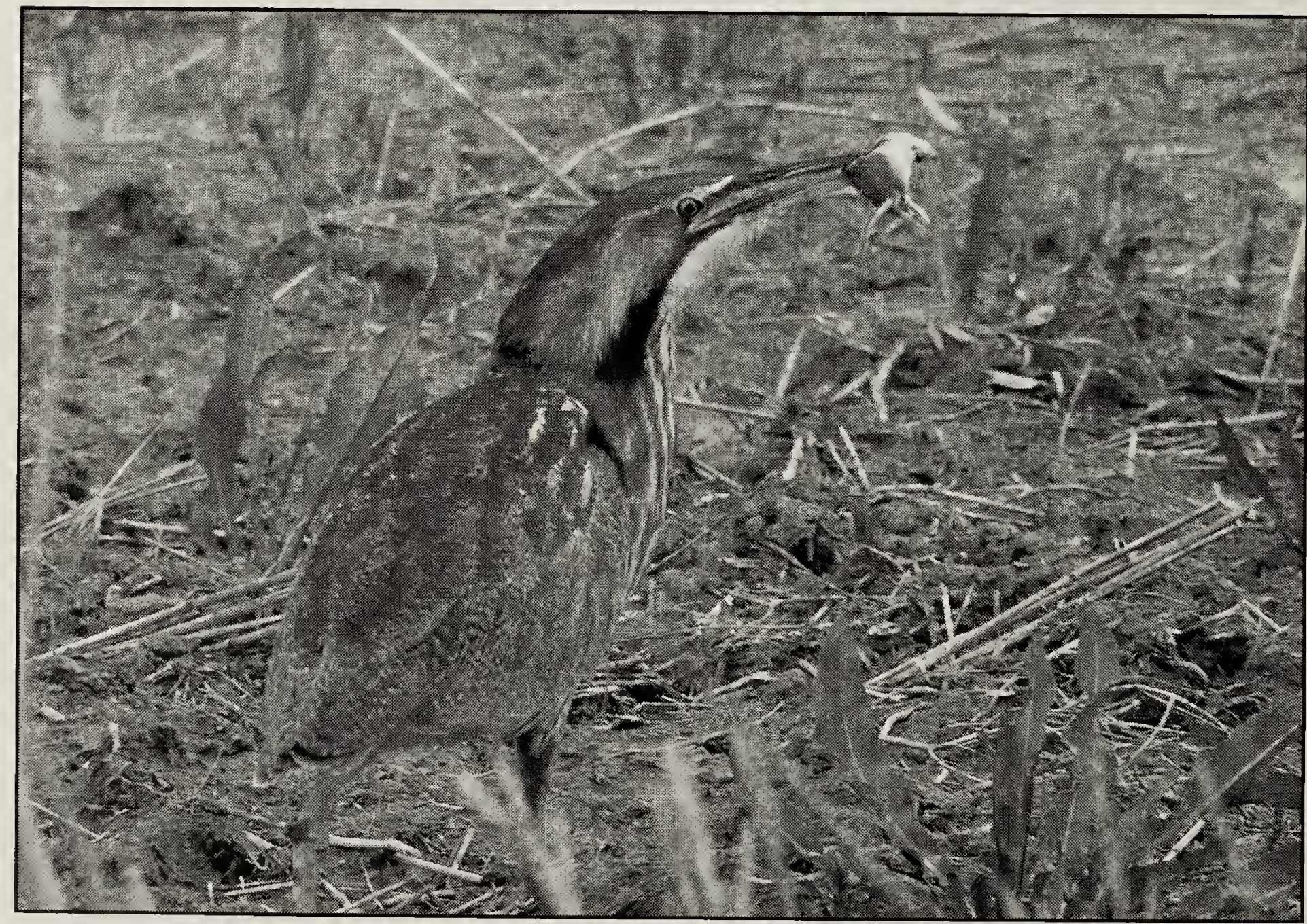

